\title{
PENDEKATAN PERILAKU TRENGGILING SUNDA DALAM PERANCANGAN PUSAT KONSERVASI
}

\author{
Nur Afifah Khairunnisa ${ }^{1)}$, Doddy Yuono ${ }^{2)}$ \\ 1)Program Studi S1 Arsitektur, Fakultas Teknik, Universitas Tarumanagara, nurafifah2801@gmail.com \\ 2) Program Studi S1 Arsitektur, Fakultas Teknik, Universitas Tarumanagara, doddyy@ft.untar.ac.id
}

\begin{abstract}
Abstrak
Indonesia merupakan negara megabiodiversitas peringkat kedua paling tinggi di dunia. Namun, dikenal juga sebagai negara yang memiliki daftar terbanyak mengenai satwa lindung yang terancam punah berdasarkan kategori International Union for Conservation of Nature (IUCN). Hal ini dikarenakan kurangnya perlindungan, lemahnya peraturan, dan minimnya wawasan serta kesadaran masyarakat. Padahal, relasi antar organisme hidup sangat penting dalam ekosistem. Sehingga, diperlukannya prinsip atau pemikiran dalam mengupayakan terpeliharanya sumber daya alam yang disebut Beyond Ecology untuk menjamin kehidupan yang berkelanjutan. Kini, beberapa hewan di Indonesia telah mencapai ambang kepunahan, salah satunya adalah trenggiling sunda (Manis Javanica) yang populasinya menurun hingga 80\% dalam kurun waktu 21 tahun terakhir dikarenakan perburuan liar dan perdagangan ilegal. Salah satu upaya pelestariannya adalah melakukan perancangan konservasi yang digabung dengan program edukasi dan rekreasi, dengan tujuan melindungi, memulihkan, dan melestarikan keberadaan trenggiling sunda sekaligus meningkatkan rasa kepedulian, kesadaran dan wawasan masyarakat akan pentingnya pelestarian keanekaragaman hayati dalam kehidupan. Dengan menggunakan metode analogi, diperlukannya analisis pendekatan perilaku dan karakteristik trenggiling sunda dalam konsep perancangan pusat konservasi sehingga menghasilkan perancangan yang sesuai dengan kebutuhan trenggiling sunda dan masyarakat Indonesia.
\end{abstract}

Kata kunci: edukasi; ekologi; konservasi; rekreasi; trenggiling sunda

\begin{abstract}
Indonesia is a country with the second highest mega-biodiversity in the world. However, it is also known as the country that has the largest list of critically endangered-protected animals based on the International Union for Conservation of Nature (IUCN) category. This is due to the lack of protection and lack of public knowledge and awareness. The relationship between living organisms is, as a matter of fact very important in the ecosystem. Thus, principles or ways of thinking are needed in the attempts of preserving natural resources to ensure a sustainable life, which are called Beyond Ecology. At the time being, several animals in Indonesia have reached the brink of extinction, one of them being the Sunda pangolin (Manis Javanica), whose population has decreased up to $80 \%$ in the last 21 years due to poaching and illegal trading. One of the efforts of preservation is to design a conservation center combined with educational and recreational programs, with the aim of protecting, restoring, and maintaining the safety of the Sunda Pangolin as well as increasing the sense of care, public awareness and knowledge of the community on the importance of biodiversity in life. By using the analogy method, it is necessary to analyze the behavior and characteristics of the Sunda pangolin in the design concept of the conservation center to produce a design that is well-suited to the needs of the Sunda pangolin and the Indonesian people.
\end{abstract}

Keywords: conservation; education; ecology; recreation; sunda pangolin 


\section{PENDAHULUAN}

\section{Latar Belakang}

Indonesia merupakan negara peringkat kedua dengan keanekaragaman hayati paling tinggi di dunia atau biasa disebut dengan negara megabiodiversitas. Namun, Indonesia dikenal juga sebagai negara yang memiliki daftar panjang mengenai satwa lindung yang terancam punah menurut data Red List yang dirilis oleh International Union for Conservation of Nature (IUCN). Dengan demikian, perlunya kesadaran masyarakat dalam menangani masalah ini demi menjaga keseimbangan ekosistem.

Kini, beberapa hewan di Indonesia telah mencapai ambang kepunahan, salah satunya adalah trenggiling sunda (Manis javanica) yang berstatus kritis, dikarenakan oleh tingkah laku manusia yang tidak bertanggung jawab. Perburuan liar dan penjualan trenggiling secara ilegal menyebabkan berkurangnya populasi di alam. Dagingnya digunakan untuk bahan dasar konsumsi hidangan mewah, sisiknya sebagai bahan dasar obat tradisional yang belum terbukti khasiatnya secara ilmiah, dan kulitnya digunakan untuk produksi aksesoris sebagai penunjang gaya hidup manusia. Hal ini menyebabkan jumlah populasinya terus menurun hingga $80 \%$ dalam kurun waktu 21 tahun terakhir.

Trenggiling sunda merupakan satwa liar yang dilindungi oleh pemerintah Republik Indonesia secara hukum dalam negeri yang tertera pada UU No. 5 Tahun 1990 tentang Konservasi Sumber Daya Alam Hayati dan Ekosistemnya serta PP No.7 Tahun 1999 tentang Pengawetan Jenis Tumbuhan dan Satwa Liar, dan dalam Konvensi Internasional Perdagangan Hewan Liar (CITES: Convention on International Trade in Endangered Species) trenggiling sunda termasuk dalam kategori Appendix I, artinya satwa liar yang dilarang dalam segala bentuk perdagangan internasional. Meskipun demikian, perburuan liar dan perdagangan ilegal tetap terjadi dikarenakan kebijakan dan sanksi yang diberikan belum cukup efektif dan belum memberikan efek jera (deterrent effect) (Takandjandji \& Sawitri, 2016).

Oleh karena itu, dibutuhkan perancangan pusat konservasi trenggiling sunda yang berbasis pada perilaku dan karakteristik trenggiling sunda itu sendiri. Sehingga, pusat konservasi akan sesuai dengan syarat dan ketentuan perancangan konservasi namun kebutuhan trenggiling sunda tetap dapat terpenuhi.

\section{Rumusan Permasalahan}

Berdasarkan penjelasan yang telah disampaikan diatas, muncul beberapa pertanyaan, yakni:

1. Apa saja perilaku trenggiling sunda?

2. Bagaimana pendekatan perilaku trenggiling sunda dapat diaplikasikan dalam perancangan pusat konservasi?

3. Rancangan desain pusat konservasi seperti apa yang sesuai dengan perilaku trenggiling sunda?

\section{Tujuan}

Membuat sebuah perancangan pusat konservasi trenggiling sunda dimana perilaku trenggiling sunda merupakan pendekatan dalam desain. Proyek ini juga diharapkan sebagai upaya pelestarian trenggiling sunda sekaligus dapat meningkatkan kesadaran, kepedulian, dan wawasan masyarakat terhadap pentingnya kehidupan trenggiling sunda dalam ekosistem. 


\section{KAJIAN LITERATUR}

\section{Beyond Ecology menurut Ahli}

Istilah ekologi dikemukakan pertama kali oleh Ernst Haeckel pada tahun 1866 yang mengartikan bahwa ekologi adalah suatu ilmu komprehensif yang mempelajari relasi baik antara organisme dan lingkungan sekitarnya. Lalu, definisi ekologi semakin berkembang dan diperjelas oleh Krebs pada tahun 1972, bahwa ekologi merupakan ilmu pengetahuan ilmiah mengenai interaksi yang menentukan distribusi dan kelimpahan suatu organisme, berkaitan dengan dimana organisme ditemukan, berapa jumlahnya, dan mengapa. Prinsip utama dalam ekologi meliputi adanya interaksi, saling ketergantungan, keanekaragaman, keharmonisan, dan adanya kemampuan berkelanjutan. Ekologi memiliki asas-asas yang sering digunakan (Manik, 2016), antara lain:

- Asas pertama ialah adanya energi pada setiap organisme, populasi, komunitas atau ekosistem.

- Asas kedua ialah tidak adanya sistem pemanfaatan energi yang efisien.

- Asas ketiga ialah materi, energi, waktu, dan keanekaragaman termasuk dalam sumber daya alam, yang berarti tidak berasal dari manusia tapi bisa dimanfaatkan untuk meningkatkan kesejahteraannya.

- Asas keempat ialah peningkatan ketersediaan sumber daya alam yang bisa mempengaruhi hal lainnya, seperti penggunaan air, energi, dll.

- Asas kelima ialah makhluk hidup yang lebih cepat beradaptasi akan lebih mampu bersaing, baik secara fisiologis maupun morfologis.

Sebagai perancang yang memikirkan kehidupan di masa yang akan datang, diharuskan memiliki prinsip-prinsip dalam mendesain secara ekologis, seperti yang dikemukakan oleh Heinz Frick pada tahun 1988, yakni:

- Elemen arsitektur yang digunakan mampu memberi perlindungan

- Penggunaan energi yang terdapat dalam material harus seminimal mungkin

- Integrasi fisik dan karakter fisik ekologi setempat

- Integrasi sistem-sistem pada bangunan dengan proses alam

- Integrasi penggunaan sumber daya yang berkelanjutan

Latar belakang konsep ekologi arsitektur adalah kerusakan lingkungan yang mengakibatkan perubahan iklim, krisis energi dan tuntutan kualitas hidup manusia. Regulasi pembangunan berwawasan lingkungan harus menjadi koridor perancangan yang tidak hanya berskala regional, namun juga skala nasional bahkan internasional (Yuliani, 2012). Dari semua pendapat ahli yang dijabarkan terdapat tujuan yang sama mengenai ekologi sehingga bisa disimpulkan bahwa melampaui ekologi merupakan suatu prinsip dalam mengupayakan terpeliharanya sumber daya alam untuk menjamin keberlangsungan siklus ekosistem didalamnya.

\section{Konservasi menurut Ahli}

Istilah konsep konservasi dikemukakan pertama kali oleh Theodore Roosevelt pada tahun 1902 yang mengatakan bahwa konservasi berasal dari kata conservation yang terdiri dari kata con (together) dan servare (keep/safe), diartikan sebuah upaya memelihara apa yang kita punya (keep/save what you have), namun secara bijaksana (wise use). Pada tahun 2007, International Union for Conservation of Nature juga mengartikan konservasi sebagai manajemen organisme hidup termasuk manusia yang dapat meningkatkan kualitas hidup manusia dan makhluk hidup lain disekitarnya. 
Conservation is humanity caring for the future, menurut Nancy Newhall. la mencoba mengartikan konservasi sebagai suatu kepedulian atau suatu hal yang dilakukan berdasarkan kemanusiaan demi menciptakan masa depan yang lebih baik dalam segala hal.

Intinya, konservasi merupakan suatu upaya perlindung atau pelestarian lingkungan yang dilakukan oleh manusia dengan cara mempertahankan keberadaan suatu komponen lingkungan untuk menjaga keseimbangan ekosistem dan memastikan keberlangsung kehidupan di dunia.

\section{Perilaku dan Habitat Trenggiling Sunda}

Trenggiling sunda beraktivitas pada malam hari atau biasa disebut dengan nokturnal, pada siang hari biasa tidur didalam liang bawah tanah atau lubang-lubang pohon, memiliki kebiasaan menggali lubang yang berfungsi menggeburkan tanah di dalam hutan, serta pemangsa serangga perusak pohon seperti semut dan rayap. Dengan demikian, eksistensi trenggiling sunda secara tidak langsung dapat menjaga keberlangsungan regenerasi ratusan jenis pohon yang ada di hutan dengan memakan hama tanaman. Perilaku makan, bergerak, tidur, mempertahankan diri, dan berkembang biak merupakan perilaku trenggiling sunda di alam bebas (Sawitri \& Takanjandji, Mariana, 2016).

Berada di habitat aslinya dengan alasan persamaan kondisi fisik dan lingkungannya, tidak ada predator, serta sumber pakan yang melimpah merupakan hal yang penting bagi trenggiling sunda dalam memilih habitatnya. Dilihat dari perilaku dan aktivitas hariannya, trenggiling sunda memiliki peluang dan prospektif untuk dikembangbiakkan di penangkaran (Masy'ud et al., 2011).

\section{Konservasi Trenggiling Sunda di Indonesia}

Pengadaan bibit satwa yang dilestarikan, sarana dan prasarana area pemeliharaan, ketersediaan pakan dan air, perawatan kondisi kesehatan, adaptasi yang ditunjukkan oleh perilaku satwa di area pemeliharaan dalam beraktivitas serta terpenuhi kebutuhan hidupnya sehingga fungsi reproduksi dan produksi dapat berlangsung baik merupakan faktor-faktor penunjang keberhasilan penangkaran (Sawitri \& Takanjandji, Mariana, 2016).

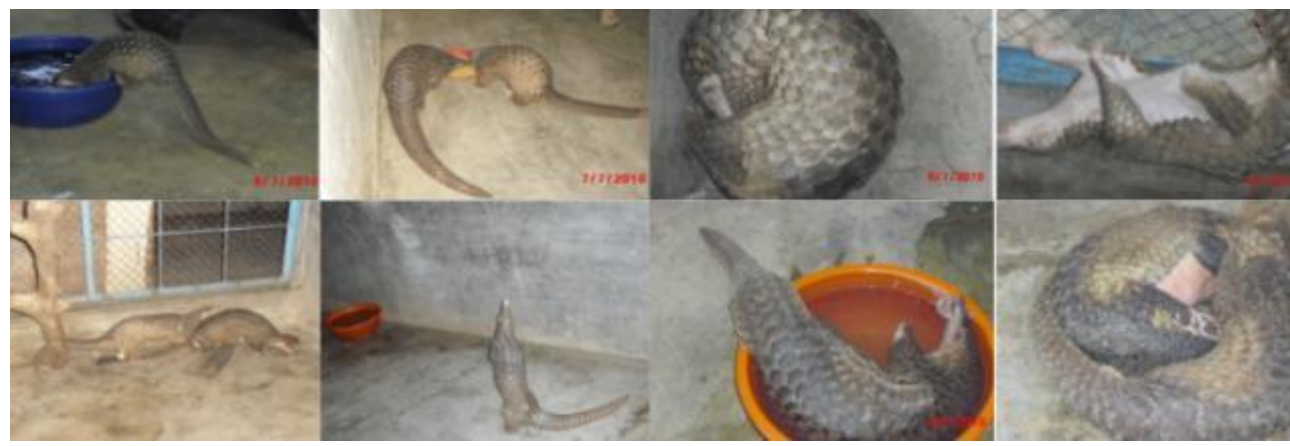

Gambar 1. Perilaku Trenggiling Sunda di Penangkaran Sumber : (Sawitri et al., 2011)

Penangkaran trenggiling sunda sudah dilakukan oleh UD. Multi Jaya Abadi di Sibolga dan Deli Serdang, Sumatera Utara sejak tahun 2009 yang berbentuk permanen berupa kandang/ pent disertai sarana dan prasarana beraktivitas sesuai dengan kebutuhan trenggiling di alam agar memudahkan proses adaptasi dengan lingkungan buatan (Sawitri et al., 2011) dan semi 
permanen berupa paddock. Trenggiling sunda di penangkaran berhasil adaptasi dengan lingkungan penangkaran dengan bukti keberhasilan memproduksi 3 bayi trenggiling sunda pada tahun 2010.

\section{METODE}

Dalam proses perancangan, penulis menggunakan metode analogi atau pendekatan perilaku dan karakteristik trenggiling sunda dan manusia yang akan menghasilkan kriteria lahan sebagai wadah perancangan dengan program yang dibutuhkan, tipologi hingga peletakan masingmasing ruang. Karena, informasi tentang status biologi reproduksi dari satwa liar sangat penting untuk pelaksanaan kegiatan konservasi ex situ (Radhi, 2019). Selanjutnya, mengikuti peraturanperaturan perancangan konservasi berdasarkan Peraturan Menteri Kehutanan no.53 tahun 2006 tentang lembaga konservasi dan Peraturan Menteri Pertanian no.70 tahun 2015 tentang Instalasi Karantina Hewan. Selanjutnya, metode yang digunakan berhubungan dengan sirkulasi yang diciptakan, sehingga diharapkan interaksi yang terjadi antar trenggiling sunda dan manusia tidak akan mengganggu satu sama lain. Terakhir, penulis mengadopsi bentuk trenggiling sunda yang dimodifikasi sesuai analisis yang dilakukan dan diterapkan dalam desain perancangan.

\section{DISKUSI DAN HASIL}

\section{Analisis Perilaku Trenggiling Sunda}

Analisis karakterisik dan perilaku trenggiling sunda akan menghasilkan respon desain terhadap kebutuhan trenggiling sunda, sehingga bisa memaksimalkan tujuan proyek sebagai area penangkaran melalui hasil penelitian yang sudah ada. Sehingga metode yang digunakan adalah metode analogi dengan mempelajari kebiasaan-kebiasaan trenggiling sunda agar dapat menghasilkan pusat konservasi yang sesuai dari segi sirkulasi, organisasi ruang, ruang interaksi antar trenggiling sunda dan manusia, dan kebutuhan lainnya.

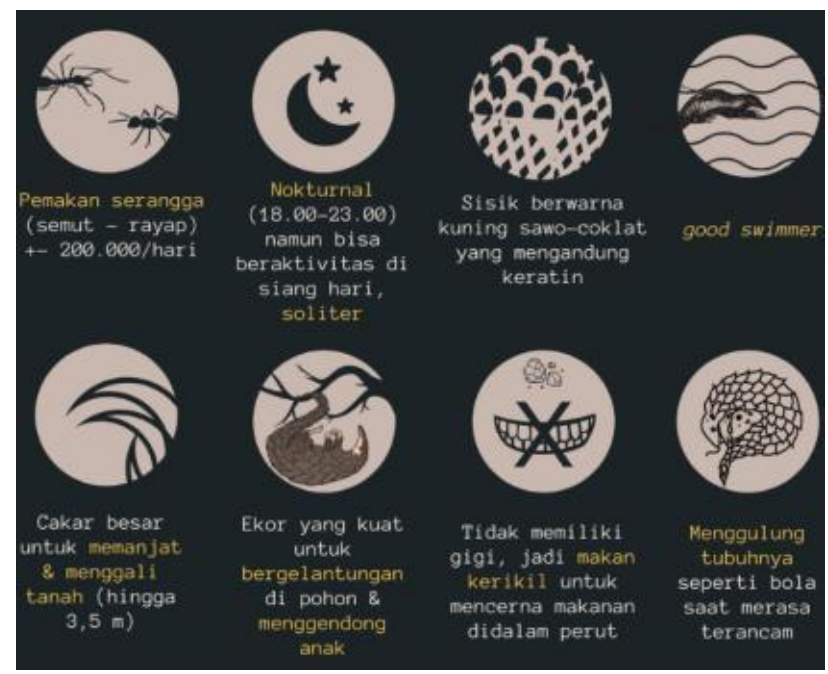

Gambar 2. Karakteristik dan perilaku trenggiling sunda

Sumber : Penulis, 2021

Informasi mengenai perilaku trenggiling dapat menunjang sistem penangkaran yang lebih baik dan meningkatkan keberhasilan penangkaran (Radhi, 2019). Dari analisis karakteristik dan perilaku trenggiling sunda bisa menghasilkan beberapa respon desain perancangan yaitu pengadaan program peternakan dan pengolahan pakan sebagai alternatif berupa budidaya 
kroto (Rianti \& Takandjandji, 2019), penerapan area pemeliharaan berupa pent dan paddock disesuaikan dengan kebutuhan, membuat kolam di area pemeliharaan, menempatkan pepohonan kedalam area pemeliharaan, memastikan batasan-batasan area pemeliharaan dengan cara melakukan pengecoran sekitar $3 \mathrm{~m}$ didalam tanah dan menggunakan penutup atap berupa kawat diseluruh bagian, serta membuat koridor observasi yang tidak terlihat oleh trenggiling sunda dengan menerapkan material one-way mirror.

\section{Analisis Program Kegiatan}

Dikarenakan program konservasi membutuhkan partisipasi masyarakat dalam hal pengelolaan, pemeliharaan, dan pelestarian dibutuhkan program pendukung. Dalam proses pemilihan program pendukung, penulis menganalisis kebutuhan mendasar trenggiling sunda dan manusia. Sehingga, hasil perancangan bisa memfasilitasi kehidupan keduanya.

Tabel 1. Segmentasi program berdasarkan kebutuhan pengguna

\begin{tabular}{|c|c|c|}
\hline Pengguna & Tujuan Perancangan bagi Pengguna & Program \\
\hline \multirow{4}{*}{$\begin{array}{c}\text { Trenggiling } \\
\text { Sunda }\end{array}$} & Mempertahankan keberlangsungan hidup & \multirow{4}{*}{ Konservasi } \\
\hline & Menciptakan ruang yang aman dari segala & \\
\hline & ancaman predator & \\
\hline & - Mencegah dan mengurangi perburuan liar \& & \\
\hline \multirow{6}{*}{ Manusia } & - Menyediakan ruang untuk melakukan & \multirow{4}{*}{ Edukasi } \\
\hline & penelitian akademis & \\
\hline & Menciptakan rasa peduli dan pengetahuan & \\
\hline & pentingnya keberlangsungan hidup trenggiling sunda & \\
\hline & Menambah destinasi eko-wisata bagi semua & \multirow{2}{*}{ Rekreasi } \\
\hline & kalangan masyarakat & \\
\hline
\end{tabular}

Sumber : Penulis, 2021

Ketiga program utama tersebut kemudian dijabarkan lebih spesifik keruangannya. Khususnya di area konservasi, diharuskannya memiliki sarana pemeliharaan satwa berupa ruang pemeliharaan, ruang pengembangbiakkan, ruang isolasi, ruang perawatan, dan prasarana pendukung pengelolaan satwa serta adanya area budidaya kroto agar trenggiling sunda memiliki ketersediaan pakan yang cukup. Hal ini diterapkan karena mengacu pada Peraturan Menteri Kehutanan No.53 Tahun 2006 tentang Lembaga Konservasi.

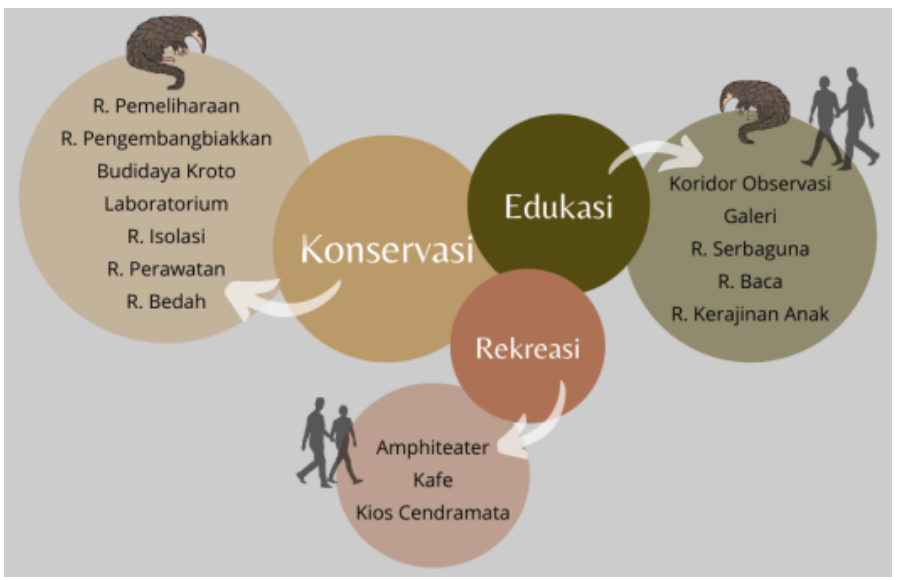

Gambar 3. Spesifikasi Program Ruang

Sumber : Penulis, 2021 


\section{Kriteria dan Analisis Kawasan Terpilih}

Dibawah ini merupakan kriteria habitat hingga strategi penangkaran berdasarkan analisis dari beberapa jurnal yang membahas informasi serupa, yaitu kawasan terpilih haruslah masih bersifat alami dan peruntukannya sebagai area konservasi. Untuk mengembangkan trenggiling di penangkaran sebaiknya dipilih trenggiling yang habitat asalnya sama dengan kondisi habitat di lokasi kandang/area penangkaran, seperti kondisi suhu, kelembaban dan ketinggian tempat (Kuswanda \& Onrizal, 2018).

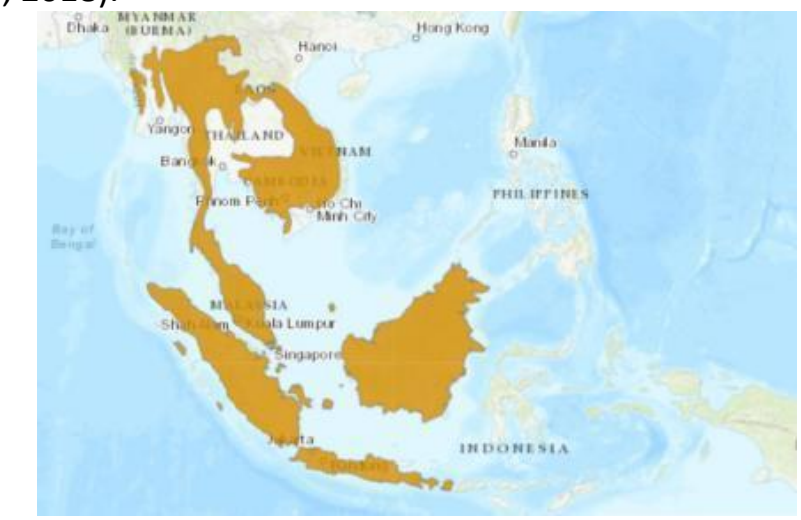

Gambar 4. Peta Persebaran Habitat Trenggiling Sunda Sumber : IUCN Red List

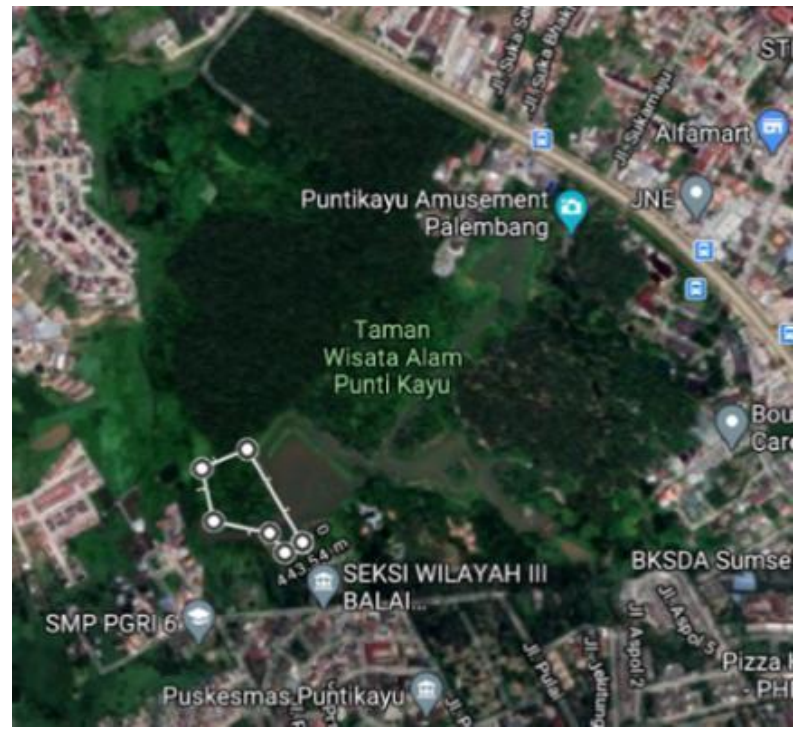

Gambar 5. Lokasi Perancangan

Sumber: Google Maps 2021

$\begin{array}{rrr}\text { Data Tapak: } & \text { Luas Lahan } & =10.008 \mathrm{~m}^{2} \\ \text { KDB } & & =60 \\ \text { KLB } & =1.8 \\ \text { KB } & =3 \\ \text { KDH } & =20 \\ \text { KTB } & =0\end{array}$

Berdasarkan penjelasan kriteria pemilihan kawasan diatas, lokasi perancangan yang dipilih berada di Taman Wisata Alam Punti Kayu Palembang tepatnya di Jl. Kol. H. Burlian, Km. 6,5, 
Karya Baru, Kecamatan Alang Alang Lebar, Kota Palembang, Provinsi Sumatera Selatan. Taman Wisata Alam Punti Kayu juga menjadi tapak yang ideal untuk perancangan konservasi spesies yang kritis, terancam, rentan, atau bernilai ekonomi tinggi (terutama: gajah, harimau, trenggiling, tapir, pelanduk, beruang madu) (Pemerintah Provinsi Sumatera Selatan, 2017).

Kawasan terpilih merupakan satu-satunya hutan dataran rendah yang masih tersisa ditengahtengah Kota Palembang yang berfungsi sebagai paru-paru kota, sehingga lokasi perancangan berbatasan langsung dengan danau TWA Punti Kayu dan area perlindungan hutan pinus, juga dikelilingi oleh area perumahan dan area rekreasi TWA Punti Kayu dalam radius 500 m, serta terdapat BKSDA Sumatera Selatan, fasilitas kendaraan umum, fasilitas kesehatan berupa RSUD Sumatera Selatan, dan Dinas Kehutanan dalam radius $1000 \mathrm{~m}$ sebagai penunjang kebutuhan program yang ada dalam proyek perancangan.

\section{Proses Pembentukan Massa}

Konsep dasar massa bangunan mengadopsi bentuk dasar dari perilaku trenggiling sunda yang dimodifikasi sesuai analisis yang dilakukan. Mulai dari kebutuhan trenggiling sunda dan manusia, klasifikasi area pengelola dan pengunjung, klasifikasi area konservasi-edukasi-rekreasi, konektivitas lahan dengan sekitarnya (Danau TWA Punti Kayu), perasaan pengunjung yang diciptakan melalui sirkulasi dari awal masuk hingga keluar proyek perancangan, serta memerhatikan orientasi matahari dan sirkulasi udara.

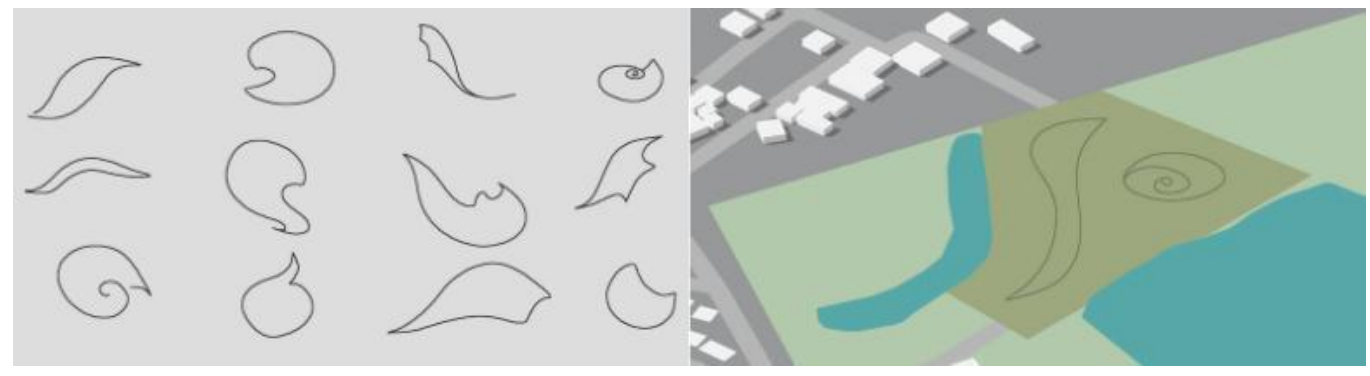

Gambar 6. Penerapan Bentuk Dasar Perilaku Trenggiling Sunda Sumber: Penulis, 2021

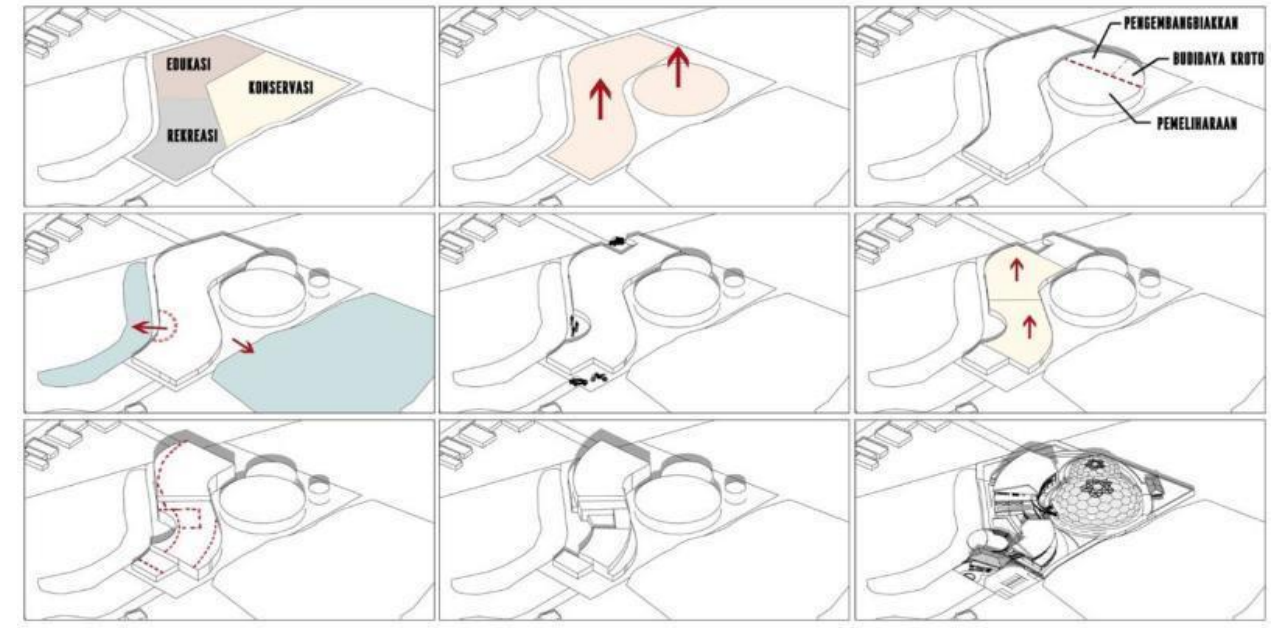

Gambar 7. Proses Pembentukan Massa

Sumber: Penulis, 2021 
Pada site, sirkulasi kendaraan dibagi menjadi 2 , yaitu kendaraan pengunjung dibagian depan dan pengelola berupa loading in dibagian belakang, sehingga aktivitas keluar-masuknya pengunjung tidak mengganggu aktivitas pengangkutan trenggiling sunda dan area pemeliharaan bebas dari kendaraan. Entrance pengunjung juga dibagi menjadi 2, yakni entrance kendaraan dan pedestrian, dimana keduanya akan disambut dengan area loket dan informasi. Area service dan pengelolaan juga diletakkan dibagian belakang tapak. Sehingga sirkulasi penjaga dan pengelola serta pengunjung terpisah.

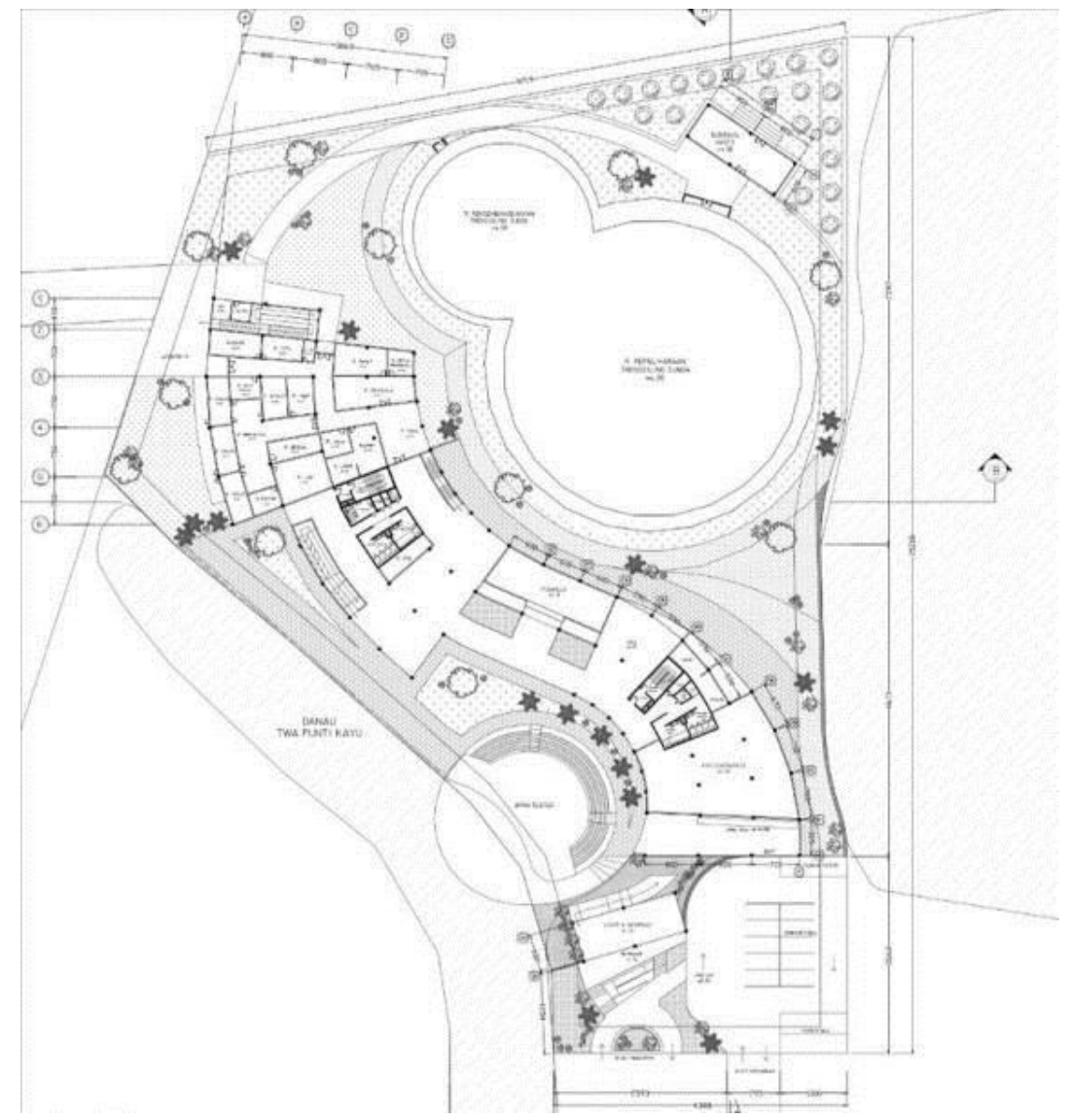

Gambar 8. Site Plan

Sumber: Penulis, 2021

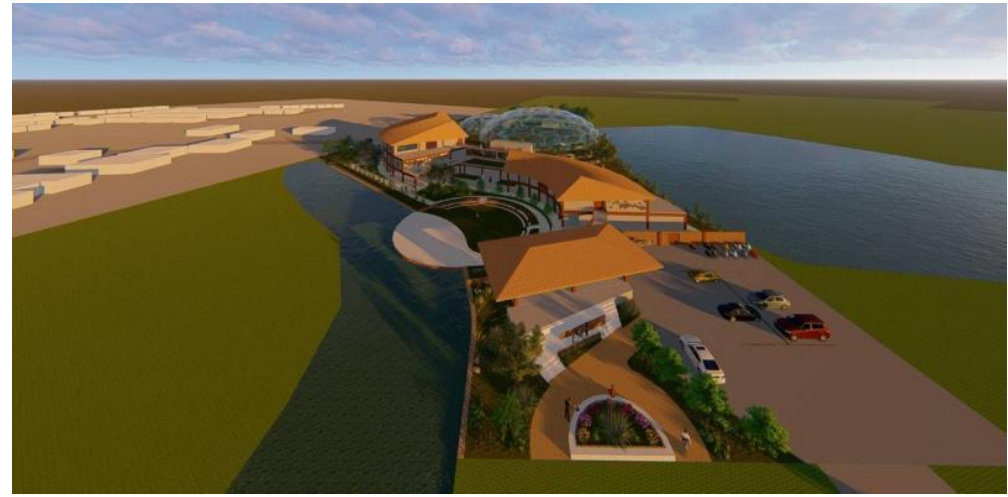

Gambar 9. Perspektif Eksterior

Sumber: Penulis, 2021 


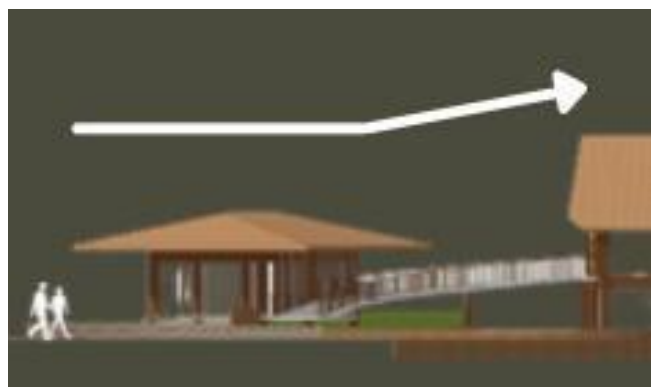

Gambar 10. Konsep Sirkulasi ntrance pengunjung

Sumber: Penulis, 2021

Dari area loket dan informasi, pengunjung akan diarahkan ke lantai 2 yaitu area galeri. Galeri berfungsi untuk memberi informasi dan edukasi terlebih dahulu mengenai trenggiling sunda seperti apa dan pentingnya pelestarian keanekargaman hayati dalam kehidupan.

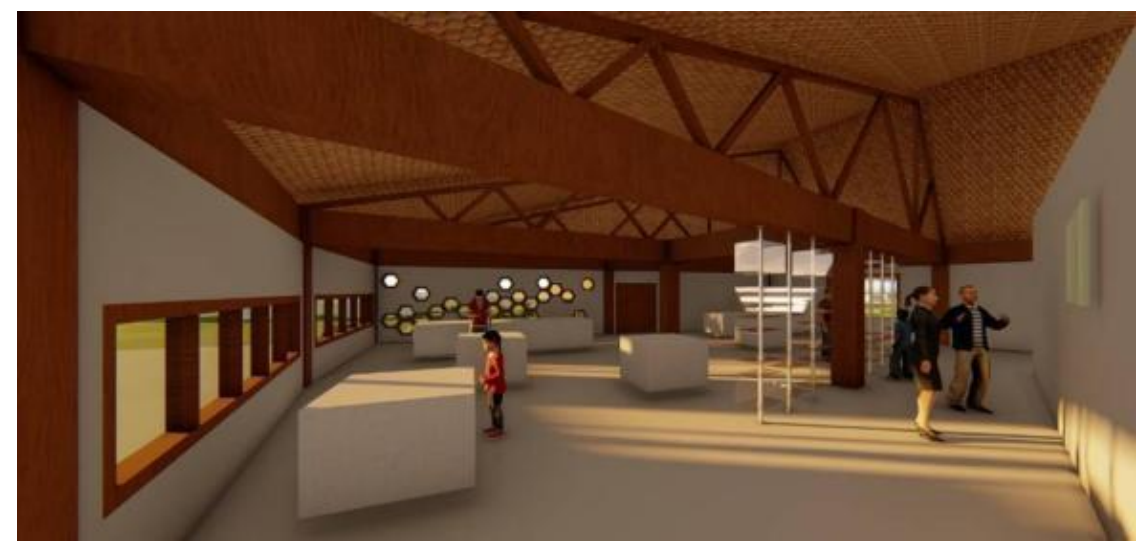

Gambar 11. Area Galeri

Sumber: Penulis, 2021

Setelah itu, pengunjung bisa langsung menuju area pemeliharaan dan pengembangbiakkan trenggiling sunda melewati konektor berupa selasar yang bertujuan untuk menciptakan suasana dan perasaan penuh semangat melalui sirkluasi yang diterapakan.

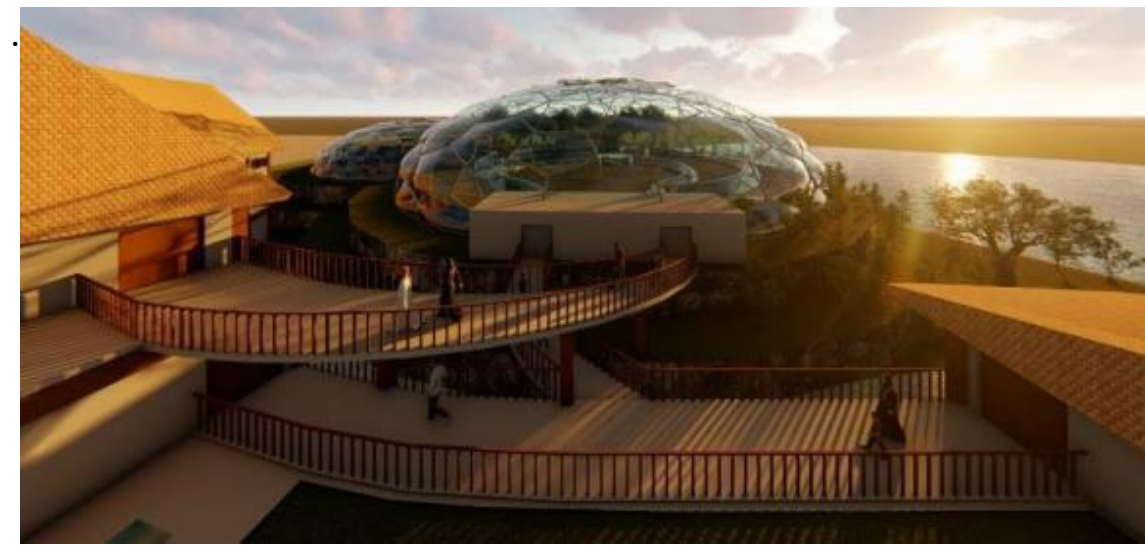

Gambar 12. Konektor Sebagai Sarana Menciptakan Alur Perasaan Pengunjung Sumber: Penulis, 2021 
Area pemeliharaan sengaja dibuat terbuka atau semi permanen, agar trenggiling sunda bisa merasakan selayaknya di alam bebas. Material yang digunakan untuk perancangan koridor berupa one-way mirror, sehingga trenggiling sunda tidak bisa melihat manusia dan merasa ketakutan atau terancam akan keberadaan manusia disekitarnya, serta menerapkan peglihatan setara dengan eye-level manusia.

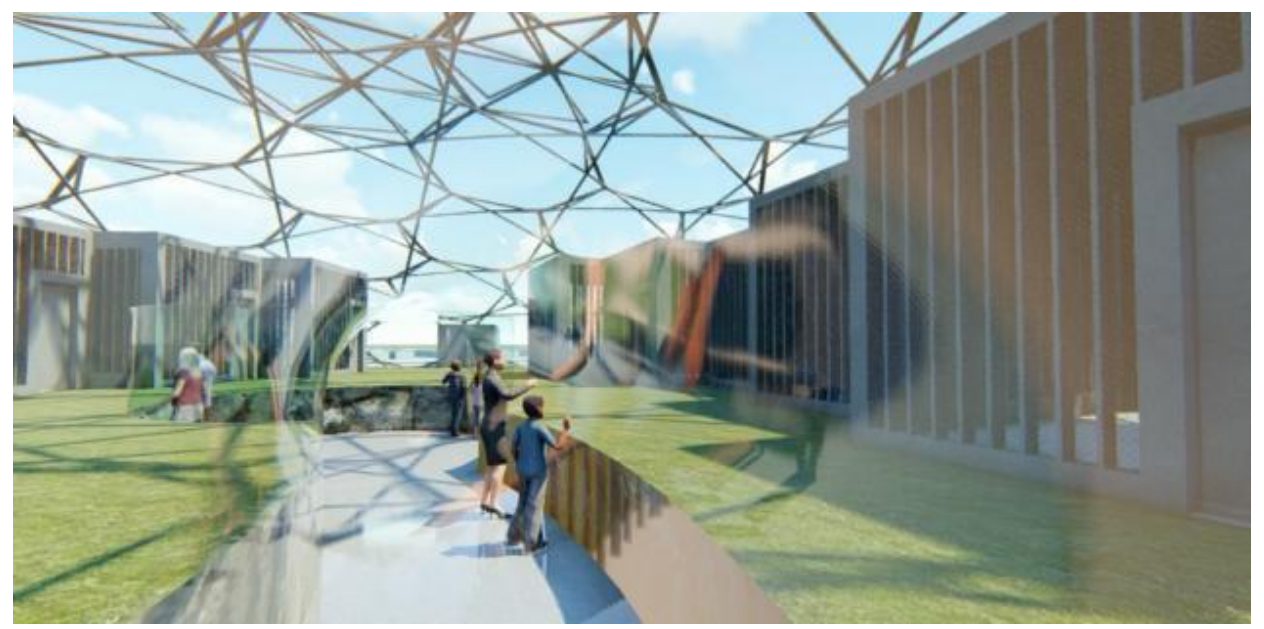

Gambar 13. Penerapan Penglihatan Setara Eye Level di Area Pengembangbiakkan Trenggiling Sunda

Sumber: Penulis, 2021

Kawasan ini merupakan kawasan dimana ketiga program disatukan, dengan fungsi utama sebagai wadah konservasi bagi trenggiling sunda, terdapat koridor yang mengelilingi area pemeliharaan sebagai wadah rekreasi baru bagi masyarakat, dan beberapa stop point untuk kebutuhan observasi yang berfungsi sebagai wadah edukasi. Sebelum masuk ke area ini juga ada ruang transisi dimana pengunjung akan diarahkan untuk menjaga ketenangan dan tidak menciptakan kebisingan saat di koridor observasi.

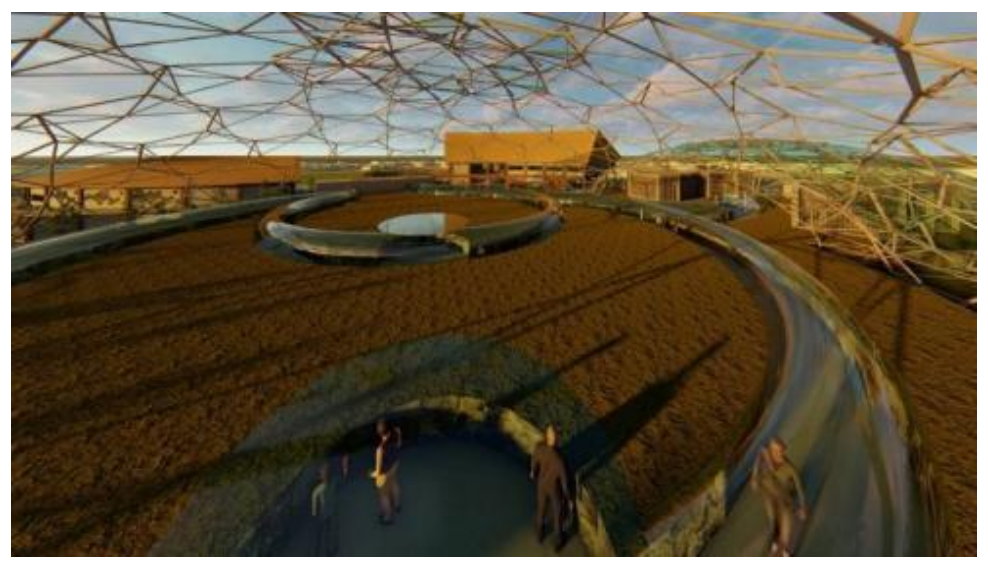

Gambar 14. Area Pemeliharaan Trenggiling Sunda Sumber: Penulis, 2021

Di bagian belakang area pemeliharaan terdapat area budidaya kroto secara alami menggunakan pohon jambu dan olah pakan alternatif secara buatan. Sehingga, ketersediaan pakan trenggiling sunda akan tetap terjaga. Area ini langsung terkoneksi dengan area pemeliharaan, 
pengembangbiakkan, area servis dan pengelola karena area ini hanya bisa diakses oleh penjaga.

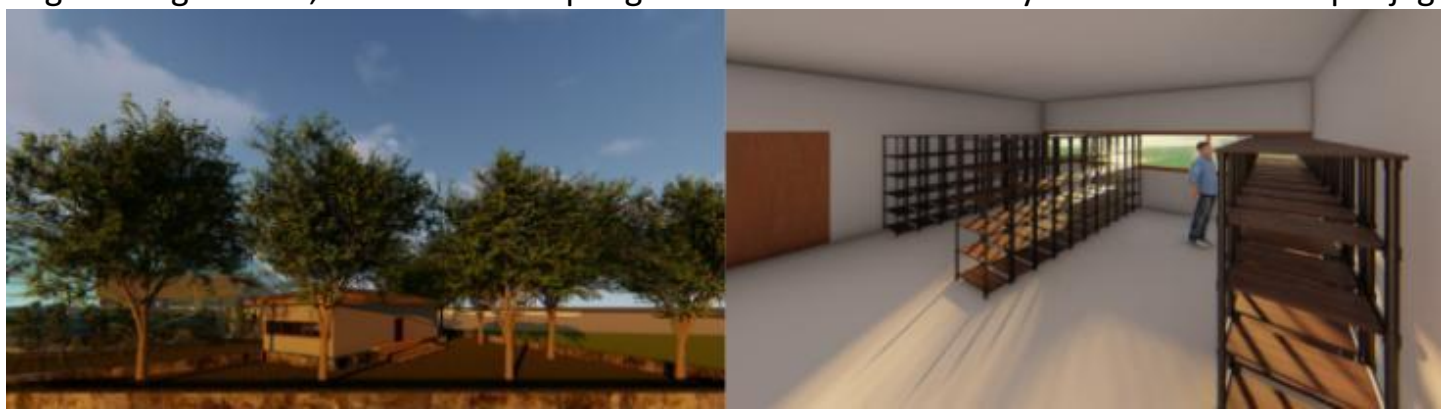

Gambar 15. Area Budidaya Kroto Secara Alami dan Buatan

Sumber: Penulis, 2021

Terdapat ruang isolasi yang berbatasan langsung dengan ruang inap penjaga atau peneliti yang membutuhkan, yang berfungsi sebagai area pengawasan trenggiling sunda selama 24 jam penuh bahkan lebih jika membutuhkan karena sedang menderita penyakit atau keperluan penelitian. Material pembatas yang digunakan adalah one way mirror sehingga manusia bisa memantau dengan jelas namun tidak sebaliknya.

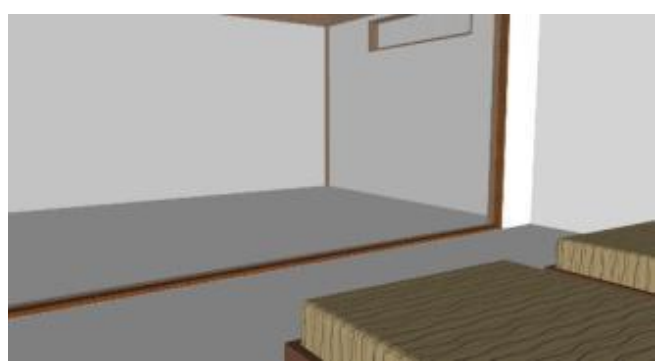

Gambar 16. Ruang Inap Penjaga/Peneliti dan Ruang Isolasi Trenggiling Sunda Sumber: Penulis, 2021

Ruang kerajinan anak dan ruang baca merupakan program edukasi yang bertujuan memberi pemahaman akan pentingnya pelestarian keanekaragaman hayati sejak dini, serta pemenuh kebutuhan peneliti bahkan pelajar yang membutuhkan.

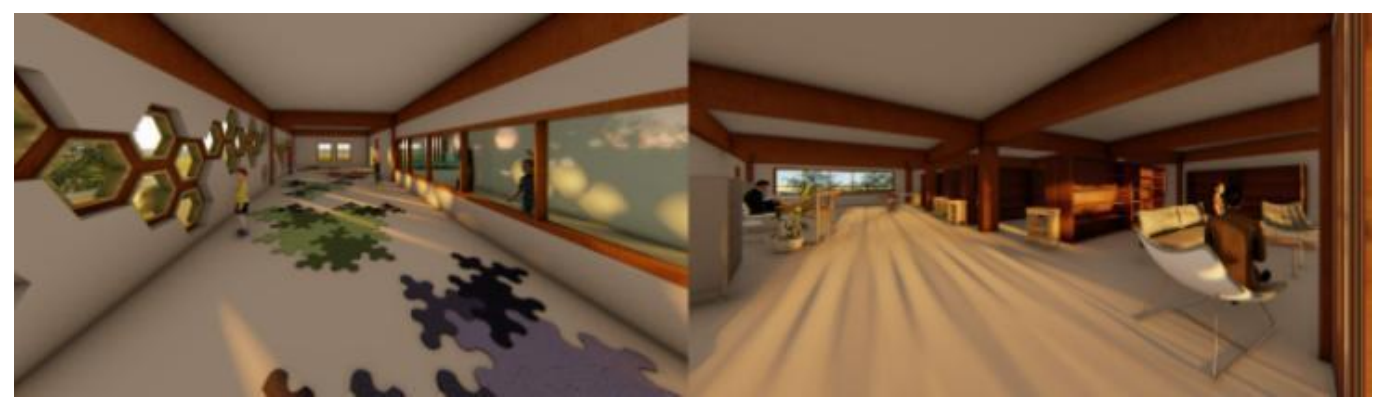

Gambar 17. Ruang kerajinan anak dan ruang baca

Sumber: Penulis, 2021

Amphiteater dan outdoor café merupakan area rekreasi pengunjung serta respon perancangan terhadap lingkungan sekitar berupa view danau TWA Punti Kayu, dengan tujuan memastikan orientasi matahari dan sirkulasi udara didalam perancangan dapat terjaga. 


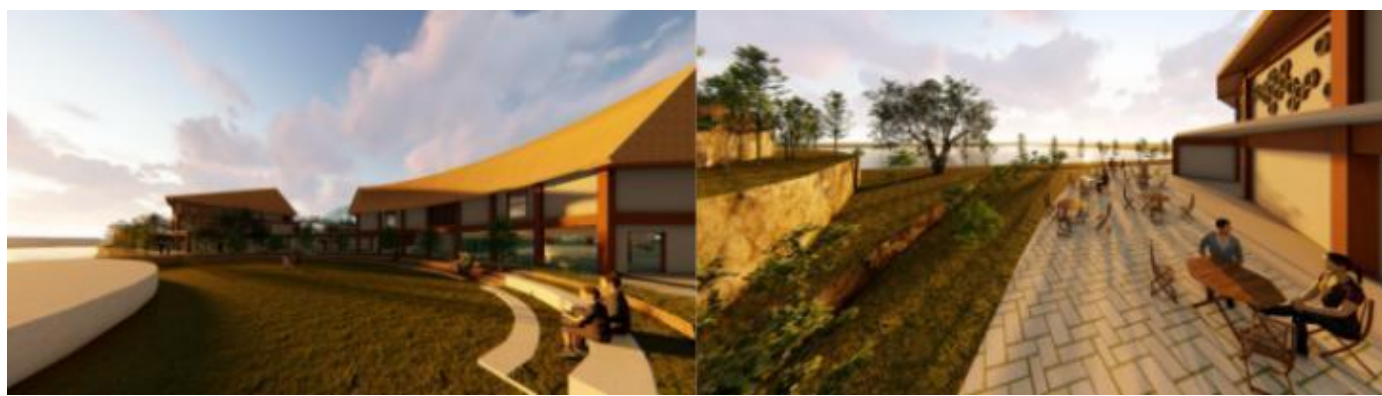

Gambar 18. Amphiteater dan Outdoor Café

Sumber: Penulis, 2021

Sebelum keluar dari area perancangan, pengunjung akan disuguhkan dengan kios cendramata dan area wall of fame dengan tujuan re-calling the memory of sunda pangolin dan mengubah cara pandang mereka terhadap trenggiling sunda. Dengan mereka membeli cendramata atau berfoto di area wall of fame dan disebarluaskan di platform sosial media juga merupakan salah satu bentuk kecil dalam menyebarluaskan akan keberadaan trenggiling sunda secara tidak langsung. Seiring berjalannya waktu, akan semakin banyak masyarakat yang peduli dan teredukasi.

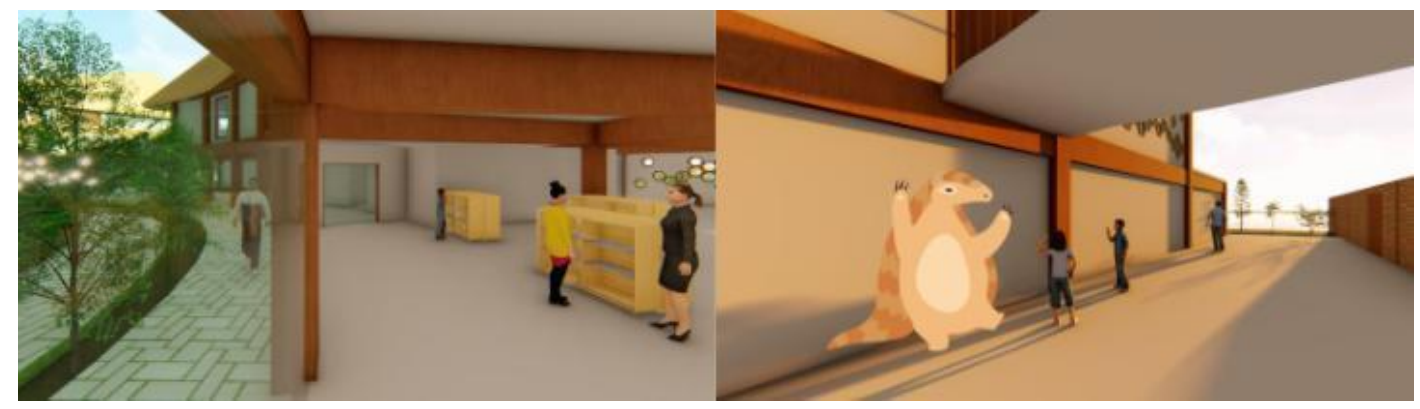

Gambar 19. Kios Cendramata dan Area Wall of Fame

Sumber: Penulis, 2021

\section{KESIMPULAN DAN SARAN}

\section{Kesimpulan}

Perancangan pusat konservasi ini berusaha membuktikan akan pentingnya relasi baik antar organisme hidup demi menjaga keberlangsungan kehidupan. Peran manusia sangatlah besar dalam menciptakan masa depan dengan siklus ekosistem yang baik. Oleh karena itu, perancangan pusat konservasi ini mencoba menjadi salah satu bentuk tanggung jawab atas perilaku manusia yang berburu trenggiling sunda secara liar dan diperjualbelikan secara ilegal. Selain itu, program-program yang ada juga disesuaikan dengan kebutuhan trenggiling sunda dan manusia agar dapat meningkatkan kualitas kehidupan bagi keduanya, dengan melakukan pendekatan perilaku trenggiling sunda dalam penerapan desain pusat konservasi dan penyelesaian masalah interaksi antar keduanya.

\section{Saran}

Dalam perancangan pusat konservasi, salah satu pendekatan desain yang dilakukan adalah pendekatan perilaku binatang/hewan (dalam hal ini trenggiling Sunda). Akan tetapi pendekatan lainnya dapat dilakukan seperti pendekatan teknologi maupun pendekatan desain yang lain, sehingga diharapkan pendekatan dengan perilaku hewan ini dapat dipakai sebagai acuan untuk 
penelitian-penelitian lainnya dalam perancangan pusat konservasi binatang. Dengan adanya proyek ini juga bisa menjadi contoh dalam merancang suatu karya arsitektur yang mementingkan prinsip ekologi. Tidak hanya mementingkan kebutuhan jangka pendek manusia saja.

\section{REFERENSI}

Kuswanda, W., \& Onrizal, O. (2018). Strategi penangkaran Trenggiling (Manis javanica) di Sumatera Utara. Talenta Conference Series: Agricultural and Natural Resources (ANR), 1(2), 227-230. https://doi.org/10.32734/anr.v1i2.241

Manik, K. E. S. (2016). Pengelolaan Lingkungan Hidup.

Masy'ud, B., Novriyanti, \& Bismark, M. (2011). Pangolin - Manis javanica Desmarest 1822 behaviour and possibility to captive breeding. Media Konservasi, 16(3), 141-148.

Pemerintah Provinsi Sumatera Selatan. (2017). Stategi dan Rencana Aksi Keanekaragaman Hayati Provinsi Sumatera Selatan (2017-2021). Dinas Kehutanan Pemerintah Provinsi Sumatera Selatan.

Radhi, M. (2019). Perilaku Trenggiling (Manis javanica) Hewan Yang Hampir Punah. 5. https://doi.org/10.31219/osf.io/45rsc

Rianti, A., \& Takandjandji, M. (2019). Pakan Alternatif pada Trenggiling Jawa (Manis Jacanica Desmarest, 1822) di Penangkaran. Berita Biologi.

Sawitri, R., Bismark, M., \& Takandjandji, M. (2011). Perilaku trenggiling (Manis javanica Desmarest, 1822) di Penangkaran Purwodadi, Deli Serdang, Sumatera Utara. Jurnal Penelitian Hutan Dan Konservasi Alam, 9(3), 285-297.

Sawitri, R., \& Takanjandji, Mariana. (2016). Konservasi Trenggiling Jawa.

Takandjandji, M., \& Sawitri, R. (2016). Analysis of Capture and Trade of Sunda Pangolin (Manis javanica Desmarest, 1822) in Indonesia. Jurnal Analisis Kebijakan Kehutanan, 13(2), 85101.

Yuliani, S. (2012). Paradigma Ekologi Arsitektur sebagai Metode Perancangan dalam Pembangunan Berkelanjutan di Indonesia. 